\title{
TEMPE KACANG KOMAK DENGAN BEBERAPA PEMBUNGKUS YANG BERBEDA SELAMA FERMENTASI
}

\author{
[Lablab Bean Tempeh With Various Types Wrapper During Fermentation Process]
}

\author{
Baiq Dwintarahma Putri, Sri Widyastuti, Wiharyani Werdiningsih* \\ Program Studi Ilmu dan Teknologi Pangan, Fakultas Teknologi Pangan dan Agroindustri, Universitas Mataram \\ *email: wiharyani@unram.ac.id
}

Diterima 9 Juli 2018/ Disetujui Oktober 2018

\begin{abstract}
Wrapper has a very important function, which is as a protection from deterioration. The type of wrapper can be used to package tempeh produced by natural and synthetic wrapper. The aimed of this research was to determine the effect of wrap types on quality of lablab bean tempeh during fermentation process. The experiment was conducted by a Randomized Complete Design (RCD) menthod with single factor (variation of lablab bean tempeh wrap) 5 types of wrapping as treatment 4 replications. The parameter were moisture content, ash content, protein content, total fungus, observation of mycellium, value of raw tempeh appearance such as compactness of mycelium, flavor, taste and tekstur. The observed were analyzed using diversity analysis (ANOVA) at 5\% level more over. The significant result were tested by using the further Test of Honest Real Difference (HRD). The results indicated that using several types of wrapping had a significant effect on protein content, preference of mysellium and the taste of lablab bean tempeh but they are not show significantly effect in ash content, moisture content, preferences of texture, and preferences of flavour. Lablab tempeh wrapped by teak leaf produces the best treatment with protein content $11.64 \%$, moisture content $63.37 \%$, and ash content $0.51 \%$, taste, aroma, texture and misellium compactness rather preferred by panelists.
\end{abstract}

Keyword : lablab bean tempeh, tempeh wrapper

\begin{abstract}
ABSTRAK
Pembungkus memiliki fungsi yang sangat penting, yaitu sebagai pelindung dari kerusakan. Jenis pembungkus yang dapat digunakan untuk mengemas tempe berasal dari jenis pembungkus alami maupun sintetis. Penelitian ini bertujuan untuk mengetahui pengaruh beberapa jenis pembungkus terhadap mutu tempe kacang komak selama proses fermentasi. Metode penelitian yang digunakan adalah metode eksperimental dengan rancang percobaan Rancangan Acak Lengkap dengan faktor tunggal yaitu jenis pembungkus tempe kacang komak, yaitu: daun pisang, daun jati, daun waru daun kakao dan plastik.Parameter yang diamati meliputi parameter kimia (kadarair, kadar abu, kadar protein) parameter pengamatan misellium, parameter pengamatan mikroorganisme (total jamur), parameter organoleptik (kekompakan misellium, aroma, tekstur dan rasa). Hasil penelitian menunjukkan bahwa perlakuan jenis pembungkus memberikan pengaruh nyata terhadap kadar protein, kesukaan kekompakan misellium dan kesukaan rasa tempe kacang komak tetapi memberikan pengaruh yang tidak berbeda nyata terhadap kadar abu, kadar air, kesukaan tekstur, dan kesukaan aroma tempe kacang komak. Jenis pembungkus daun jati menghasilkan tempe kacang komak terbaik dengan kadar protein $11,52 \%$, kadar air 63,64\%, kadar abu 0,51\%, rasa disukai, dan aroma, tekstur, dan kekompakan misellium agak disukai panelis.
\end{abstract}

Kata kunci : tempe kacang komak, pembungkus tempe.

\section{PENDAHULUAN}

Tempe merupakan bahan makanan hasil fermentasi kedelai atau jenis kacang-kacangan lainnya menggunakan jamur Rhizopus oligosporus dan Rhizopus oryzae. Tempe umumnya dibuat secara tradisional dan merupakan sumber protein nabati yang murah harganya. Di Indonesia pembuatan tempe sudah menjadi industri rakyat (Francis, 2000).
Umumnya bahan baku yang digunakan untuk membuat tempe adalah kedelai. Primer Koperasi Tahu Tempe Indonesia (Primkopti) mengemukakan bahwa pada tahun 2012 dari kebutuhan kedelai dalam negeri sebesar 2,2 juta ton, hanya 600 ribu ton yang mampu dipenuhi oleh petani lokal, sementara 1,6 juta ton masih harus diimpor dari Amerika Serikat. Sebanyak $50 \%$ dari konsumsi kedelai di 
Indonesia dilakukan dalam bentuk tempe, $40 \%$ tahu dan $10 \%$ dalam bentuk produk lain (seperti tauco, kecap dan lain-lain). Konsumsi tempe rata-rata per orang per tahun di Indonesia saat ini diduga sekitar $6,45 \mathrm{~kg}$ (Astawan, 2004).

Untuk mengatasi ketergantungan kebutuhan kedelai perlu dilakukan substitusi dengan kacang lokal atau mengganti bahan baku kedelai dengan kacang yang lain seperti komak. Kacang komak (Lablab purpureus) adalah sejenis kacang kacangan yang berasal dari Afrika, India, dan Asia Tenggara.Kacang komak juga dapat ditemukan dengan mudah di Indonesia. Kacang komak umumnya dapat tumbuh di daerah tropis dengan ketersediaan air yang terbatas. Dibandingkan dengan kedelai, kacang komak memiliki kandungan protein yang lebih rendah. Menurut Duke (1983) kandungan protein yang dimiliki kacang komak yaitu sebesar 21,5 gram dalam 100 gram bahan, sedangkan untuk kandungan protein kedelai dari data yang ditunjukan United States Departement of Agriculture yaitu sebesar 36,4 gram didalam 100 gram bahan. Namun, keunggulan kacang komak dibandingkan dengan kedelai terletak pada tingkat ketersediaannya yang jauh lebih tinggi dari pada kedelai. Keunggulan lainnya yaitu, kacang komak dapat tumbuh di lahan marjinal, berfungsi sebagai penyubur tanah, tidak membutuhkan input produksi yang banyak, produktifitas relatif tinggi, tahan hama dan penyakit, seluruh bagian tanaman bisa dimanfaatkan ternak. Keunggulan yang dimiliki oleh kacang komak khususnya dari segi ketersediaan dapat secara langsung mengurangi beban untuk memenuhi kebutuhan pada kedelai yang sangat tinggi, sehingga kacang komak dapat dijadikan alternatif yang sangat tepat untuk mengganti kedelai sebagai bahan baku utama dalam produksi tempe.

Proses pengolahan produk tempe komak ini dilakukan dengan cara yang sama dengan produk tempe kedelai pada umumnya. Proses pembuatan tempe yang dimaksud meliputi dua tahap, yaitu proses perebusan dan proses fermentasi. Selama proses fermentasi, kedelai akan mengalami perubahan fisik, terutama tekstur. Tekstur kedelai akan menjadi semakin lunak karena terjadi penurunan selulosa menjadi bentuk yang lebih sederhana. Hifa kapang juga mampu menembus permukaan kedelai sehingga dapat menggunakan nutrisi yang ada pada biji kedelai. Hifa kapang akan mengeluarkan berbagai macam enzim ekstraseluler dan menggunakan komponen biji kedelai sebagai sumber nutrisinya (Hidayat dkk, 2006).

Selain perubahan fisik terdapat perubahan citarasa tempe yang dapat disebabkan oleh pembungkus. Penggunaan pembungkus dalam fermentasi akan mempengaruhi citarasa tempe yang dihasilkan. Di samping karena faktor koreksi lingkungan yang dibentuk oleh pembungkus tersebut dalam proses fermentasi, juga karena adanya reaksi yang mungkin terjadi antara bahan yang di fermentasi dari komponen pembungkus. Terdapat dua jenis pembungkus tempe yang digunakan selama ini, yaitu jenis pembungkus tradisional dan modern. Untuk pembungkus tradisional yang biasa digunakan yaitu berupa dedaunan seperti, daun pisang dan daun jati. Sedangkan untuk pembungkus modern untuk produk tempe digunakan pembungkus plastik. Di lingkungan sekitar terdapat beberapa jenis daun yang berpotensi untuk digunakan sebagai pembungkus seperti daun waru maupun daun kakao. Oleh karena itu telah dilakukan penelitian tentang penggunaan jenis pembungkus yang berbeda terhadap mutu tempe kacang komak selama fermentasi.

\section{BAHAN DAN METODE}

\section{Bahan}

Penelitian ini dilaksanakan di Laboratorium Pengolahan Pangan, Laboratorium Mikrobiologi Pangan dan Laboratorium Biokimia Pangan Fakultas Teknologi Pangan dan Agroindustri, serta Laboratorium Kimia Analitik Fakultas Matematika dan Ilmu Pengetahuan Alam, Universitas Mataram.

Bahan utama yang digunakan dalam penelitian ini adalah biji kacang komak yang diperoleh dari pengepul di pasar Renteng, 
Versi Online:

http://www.profood.unram.ac.id/index.php/profood e-ISSN: 2443-3446

Praya, Lombok Tengah, laru ragi tempe merk Raprima, dan beberapa jenis pembungkus.

\section{Metode}

Rancangan yang digunakan dalam penelitian ini adalah Rancangan Acak Lengkap (RAL) dengan faktor tunggal yaitu variasi jenis pembungkustempekacang komak (K) dengan 5 jenis pembungkus. Adapun perlakuan dalam penelitian ini jenis pembungkus adalah daun pisang, daun jati, daun waru, daun kakao, dan plastik. Masing-masing perlakuan diulang sebanyak 4 kali sehingga diperoleh 20 unit percobaan. Data dari hasil pengamatan kimia dan organoleptik dianalisis menggunakan analisis keragaman (Analysis of Variance) pada taraf nyata $5 \%$ dengan menggunakan software Co-Stat. Jika terjadi perbedaan yang nyata hasil pengamatan kimia dan organoleptik dilakukan uji lanjut menggunakan uji Beda Nyata Jujur (BNJ) 5\%. Sedangkan pada pengamatan hasil uji mikrobiologi menggunakan metode deskriptif.Parameter yang dianalisis meliputi kadar air (Sudarmadji, Haryono dan Suhardi, 2007), kadar abu (Sudarmadji, dkk.,2007), kadar protein (Sudarmadji, dkk., 2007), total kapang (Fardiaz, 1992) dan uji organoleptik meliputi aroma, tekstur dan rasa (Rahayu, 1998). Skala numerik untuk kesukaan aroma, tekstur, dan rasa yaitu: $1=$ sangat tidak suka, 2 = tidak suka, $3=$ agak suka, $4=$ suka, $5=$ sangat suka.

\section{Prosedur penelitian}

\section{Pembuatan Tempe Kacang Komak}

Pembuatan tempe kacang komak dilakukan dengan memodifikasi prosedur tahapan pembuatan tempe menurut (SNI 3144 : 2009). Adapun tahapan pembuatan tempe kacang komak sebagai berikut :

\section{Persiapan Bahan Baku}

Bahan baku yang digunakan adalah biji kacang komak sebanyak $1 \mathrm{~kg}$ yang diperoleh pengepul di pasar Renteng, Praya, Lombok Tengah. Daun untuk pembungkus didapatkan dari beberapa kebun di kawasan Praya, Lombok Tengah.

\section{Sortasi}

Pro Food (Jurnal Ilmu dan Teknologi Pangan)

Vol 4 No. 2 November 2018

ISSN: 2443-1095

Sortasi bertujuan untuk menyeragamkan ukuran, serta kualitas biji komak yang layak untuk digunakan, menyisihkan biji kacang komak yang kecil, berwarna hitam dan cacat.

\section{Pencucian I}

PencucianI bertujuan untuk menghilangkan kotoran yang terdapat pada biji komak.Pencucian dilakukan menggunakan air bersih yang mengalir selama \pm 5 menit.

3. Perebusan I

Perebusan I dilakukan selama \pm 30 menit pada suhu mendidih.Perebusan ini dilakukan dengan perbandingan biji kacang komak dan air yaitu $1 \mathrm{~kg}: 1,5$ liter. Perebusan ini bertujuan untuk mempermudah pengupasan kulit ari kacang komak.

4. Pencucian II

Pencucian II dilakukan menggunakan air bersih yang mengalir selama \pm 2 menit.

\section{Perendaman}

Perendaman menggunakan air bersih selama \pm 24 jam. Perendaman dilakukan secara terbuka yang bertujuan memudahkan pelepasan kulit ari pada biji komak.

5. Pengupasan Kulit Ari

Pengupasan kulit ari dilakukan dengan cara meremas-remas biji komak dengan menggunakan tangan yang telah distrilkan sebelumnya.

6. Pencucian III

Setelah kulit ari dilepas, dilakukan pecucian III menggunakan air bersih yang mengalir hingga biji komak benar benar bersih. Pencucian ini dilakukan selama \pm 1 menit

7. Perebusan II

Komak yang telah bersih kemudian direbus pada suhu mendidih dengan menggunakan lama waktu perebusan selama 30 menit. Perebusan 30 menit dilakukan dengan perbandingan biji kacang komak dan air yaitu $1 \mathrm{~kg}$ : 1,5 liter. Perebusan ini bertujuan untuk memperlunak kacang komak.

8. Penirisan dan Pendinginan

Setelah biji komak direbus, maka dilakukan penirisan dan pendinginan dengan meletakkan biji komak pada tampah. 
9. Peragian

Biji komak yang telah dingin (hangat kuku) ditimbang masing-masing sebanyak 50 gram dan ditambahkan laru dengan konsentrasi masing-masing $0,2 \%$.

10. Pembungkusan

Pembungkusan dilakukan dengan menggunakan pembungkus sesuai perlakuanyang telah diletakkan pada cetakan, agar ukuran saat pembungkusan menjadi seragam.

11. Fermentasi

Proses fermentasi dilakukan selama 48 jam dengan cara menyusun setiap bungkusan tempe menggunakan rak sederhana.

\section{HASIL DAN PEMBAHASAN}

\section{Mutu Kimia Tempe Kacang Komak}

\section{Kadar Air}

Berdasarkan hasil analisis menunjukkan bahwa jenis pembungkus tidak memberikan pengaruh nyata terhadap kadar air tempe kacang komak (Tabel 1). Kadar air tempe kacang komak dengan perlakuan jenis pembungkus berada pada kisaran 62,99\%$65,18 \%$.

Hal ini diduga karena bahan pembungkus yang berasal dari daun kedap cahaya (tidak tembus cahaya), sirkulasi udara (aerasi) dapat terjadi dengan baik melalui celah-celah pada daun sehingga oksigen lebih mudah masuk kedalam pembungkus. Dengan sirkulasi udara yang baik menyebabkan kelembaban dapat terjaga dengan baik pula, hal ini yang menyebabkan kandungan kadar air pada tempe kacang komak semua perlakuan tidak berbeda nyata.

Tabel 1. Purata Hasil Pengamatan Pengaruh Beberapa Pembungkus terhadap Kadar Air Tempe Kacang Komak Selama Fermentasi

\begin{tabular}{cc}
\hline Jenis Pembungkus & $\begin{array}{c}\text { Purata Kadar Air } \\
\text { (\%) }\end{array}$ \\
\hline Daun Pisang & $65,18 \pm 0,81$ \\
Daun Jati & $63,64 \pm 1,84$ \\
Daun Waru & $62,99 \pm 0,48$ \\
Daun Kakao & $63,37 \pm 1,32$ \\
Plastik & $64,05 \pm 0,55$ \\
\hline BNJ 5\% & - \\
\hline
\end{tabular}

Menurut Hidayat dkk (2006) faktor utama yang menentukan bahwa pembungkus
ISSN: 2443-1095

dapat menghasilkan tempe yang baik ialah aerasi dan kelembaban. Jika tempat pengemasan dapat menjamin aerasi yang merata secara terus menerus dan sekaligus dapat menjaga agar kelembaban tetap tinggi tanpa menumbulkan pengembunan. Tempe kacang komak dengan jenis pembungkus daun jati, daun waru, daun kakao dan plastik memenuhi syarat mutu tempemenurut SNI 3144 : 2009, yaitu kandungan kadar air pada produk tempe maksimal sebesar $65 \%$.

\section{Kadar Protein}

Perbedaan jenis pembungkus memberikan pengaruh yang berbeda nyata terhadap kadar protein tempe kacang komak. Hal ini diduga karena perbedaan kandungan kimia jenis pembungkus yang digunakan. Kadar protein tempe kacang komak dengan perlakuan jenis pembungkus berada pada kisaran 10,31\%-11,52\% (Tabel 2).

Menurut (Minife, 1970); (Osman, Nasarudin, dan Lee, 2004), kandungan daun kakao antara lain polifenol, teobromin, kafein, antosianin, leukoantosianin, dan katekol dengan jumlah yang bervariasi berdasarkan umur daun dan umur tanaman.

Tabel 2. Purata Hasil Pengamatan Pengaruh Beberapa Pembungkus terhadap Kadar Protein Tempe Kacang Komak Selama Fermentasi

\begin{tabular}{cc}
\hline Jenis Pembungkus & $\begin{array}{c}\text { Purata Kadar } \\
\text { Protein (\%) }\end{array}$ \\
\hline Daun Pisang & $10,78 \pm 0,17 \mathrm{ab}$ \\
Daun Jati & $11,52 \pm 0,41 \mathrm{a}$ \\
Daun Waru & $11,06 \pm 0,82 \mathrm{ab}$ \\
Daun Kakao & $11,64 \pm 0,50 \mathrm{a}$ \\
Plastik & $10,31 \pm 0,35 \mathrm{~b}$ \\
\hline BNJ 5\% & 0,76 \\
\hline
\end{tabular}

Kandungan polifenol $28,4 \mathrm{mg} / 100 \mathrm{mg}$, caffeine $1,33 \mathrm{mg} / 100 \mathrm{mg}$, dan epicatechin $2,82 \mathrm{mg} / 100 \mathrm{mg}$. Daun kakao memiliki komponen yang sama dengan daun teh (Camellia sinensis dan Camellia assmica) yaitu berupa tea polyphenol 3,60\%; favonoid glycoside1,91\%; theobromine ,71\%; catechins; dan tea pigments.

\section{Mutu Mikrobiologi Tempe Kacang Komak}

\section{Total Kapang}

Purata total jamur tempe kacang komak dengan menggunakan beberapa jenis pembungkus dapat dilihat pada Tabel 3. 


\begin{tabular}{lcr} 
Tabel 3. $\begin{array}{l}\text { Pengaruh } \\
\text { Pembungkus } \\
\text { Kapang Tempe Keberapa } \\
\text { Selama Fermentasi }\end{array}$ & $\begin{array}{r}\text { Jenis } \\
\text { Total } \\
\text { Komak }\end{array}$ \\
\hline $\begin{array}{l}\text { Jenis } \\
\text { Pembungkus }\end{array}$ & $\begin{array}{c}\text { Total Kapang } \\
\text { (CFU/g) }\end{array}$ \\
\hline Daun Pisang & $5,9 \times 10^{3}$ \\
Daun Jati & $2,5 \times 10^{3}$ \\
Daun Waru & $4,9 \times 10^{3}$ \\
Daun Kakao & $2,4 \times 10^{3}$ \\
Plastik & $2,0 \times 10^{3}$ \\
\hline
\end{tabular}

Berdasarkan Tabel 3. terlihat bahwa purata total kapang tempe kacang komak dengan perlakuan penggunaan daun pisang menunjukkan hasil tertinggi yaitu sebesar $5,9 \times 10^{3} \mathrm{CFU} / \mathrm{gram}$. Hal ini diduga disebabkan oleh adanya kandungan polifenol pada daun pisang, daun jati, daun waru maupun daun kakao yang dapat menghambat pertumbuhan bakteri. Osman, Nasarudin, dan Lee (2004) mengebutkan bahwa ekstrak daun kakao muda mengandung polifenol dan antioksidan dan Karrupiah dan Mustaffa (2013); (Meenashree, Vasanthi, dan Mary, 2014) mengemukakan bahwa ekstrak daun pisang dapat menghambat bakteri patogen $E$. coli, $P$. aeruginosa dan Citrobacter sp dengan zona penghambatan berkisar 8,0-18,6 mm (kriteria moderat) dan menghambat kapang Aspergillus terreus dan Penicillium solitum.

\section{Pengamatan Misellium}

Berdasarkan hasil pengamatan yang dilakukan, misellium tempe kacang komak dengan perlakuan pembungkus daun pisang, daun waru, daun kakao dan juga plastik pada kenampakan makroskopis terlihat misellium yang ada berwarna putih, sedangkan pada perlakuan pembungkus dengan daun jati berwarna putih dengan bercak merah yang dihasilkan dari kandungan pigmen pada daun jati. Ati dkk (2006) menyatakan daun jati muda memiliki kandungan pigmen alami yang terdiri dari pheopitin, $\beta$-karoten, pelargonidin, 3-glukosida, pelargonidin 3,7-diglukosida, klorofil dan dua pigmen lain yang belum diidentifikasi. Pelargonidin merupakan golongan pigmen antosianidin, yaitu aglikon antosianin yang terbentuk bila antosianin dihidrolisis dengan asam. Kandungan ini berfungsi sebagai pembentuk warna (pemberi pigmen) yang menyebabkan ekstrak daun jati berwarna merah.

\section{Mutu Kimia}

\section{Kadar Abu}

Berdasarkan data hasil pengamatan menunjukkan bahwa penggunaan beberapa jenis kemasan memberikan pengaruh yang tidak berbeda nyata terhadap kadar abu tempe kacang komak.

Kadar abu tempe kacang komak dengan beberapa jenis pembungkus berkisar antara 0,2\%-0,5\%. Kadar abu pada tempe kacang komak dengan perlakuan pembungkus daun pisang sebesar $0,49 \%$, daun jati $0,51 \%$, daun waru 0,53\%, daun kakao 0,50\% dan plastik sebesar 0,46\%. Kadar abu tempe kacang komak pada semua perlakuan memenuhi syarat mutu produk tempe menurut SNI 3144: 2009 yaitu kadar abu maksimal sebesar $1,5 \%$.

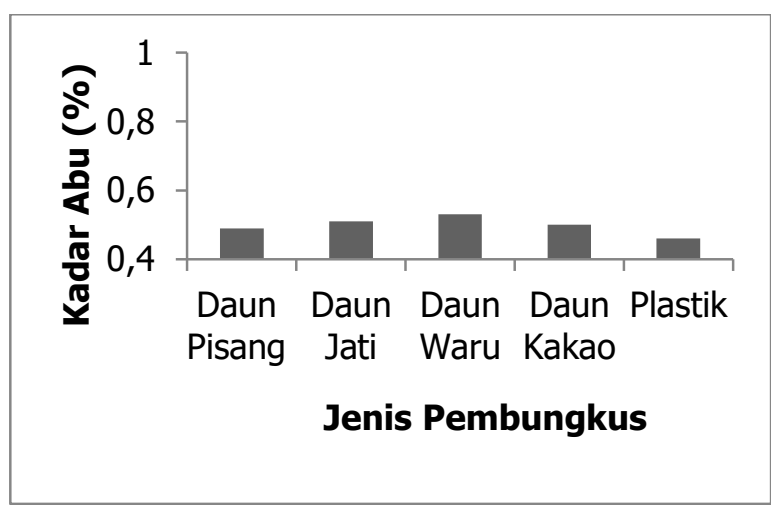

Gambar 3. Grafik Pengaruh Beberapa Jenis Pembungkus terhadap Kadar Abu Tempe Kacang Komak Selama Fermentasi

\section{Mutu Organoleptik}

\section{Kekompakan Misellium}

Misellium merupakan struktur yang menyerupai benang halus/biomassa kapang berwarna putih yang mengikat biji. Nilai kesukaan terhadap kekompakan misellium tempe kacang komak dengan pembungkus plastik berbeda nyata dengan tempe komak pembungkus daun jati dan daun waru. Penerimaan panelis terhadap kesukaan kekompakan misellium tempe kacang komak dapat dilihat pada Gambar 4.

Berdasarkan Gambar 4 terlihat bahwa panelis lebih menyukai tempe kacang komak yang dibungkus dengan daun pisang, daun jati, daun waru, maupun daun kakao. Menurut panelis, tempe tersebut menghasilkan 
Versi Online:

http://www.profood.unram.ac.id/index.php/profood e-ISSN: 2443-3446

miselium yang agak lebat dan agak kompak mirip dengan tempe kedelai. Kelebatan misellium ini diduga karena adanya kandungan antioksidan pada masing-masing daun pembungkus yang bekerja menghambat bakteri lain untuk tumbuh sehingga memaksimalkan pertumbuhan kapang pada proses fermentasi.

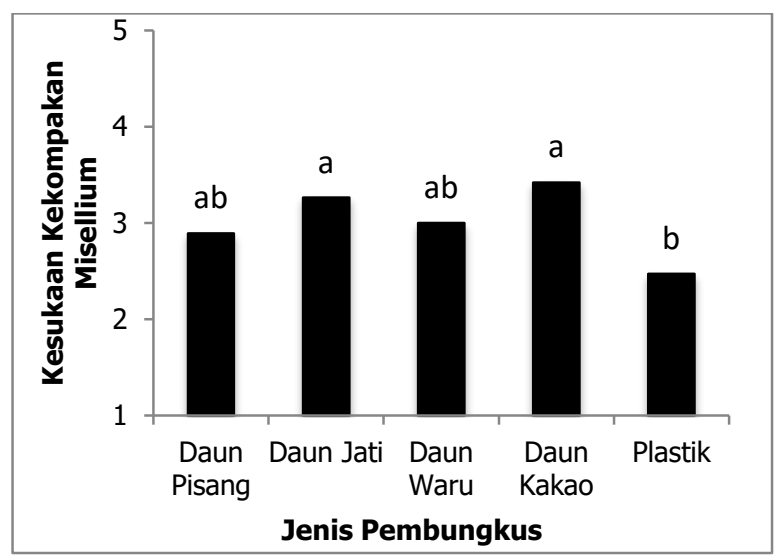

Gambar 4. Grafik Pengaruh Beberapa Jenis Pembungkus terhadap Kesukaan Kekompakan Misellium Tempe Kacang Komak Selama Fermentasi.

\section{Kesukaan Aroma}

Berdasarkan data hasil pengamatan dapat dilihat bahwa penggunaan jenis pembungkus yang berbeda memberikan pangaruh yang tidak berbeda nyata terhadap kesukaan aroma tempe kacang komak. Penilaian panelis terhadap kesukaan aroma tempe kacang komak dapat dilihat pada Gambar 5.

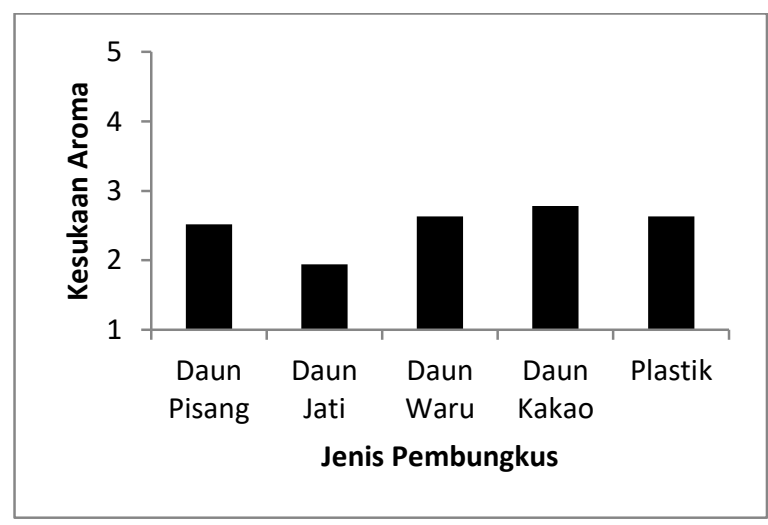

Gambar 5. Grafik Pengaruh Beberapa Jenis Pembungkus terhadap Kesukaan Aroma Tempe Kacang Komak Selama Fermentasi.
Pro Food (Jurnal Ilmu dan Teknologi Pangan)

Vol 4 No. 2 November 2018

ISSN: 2443-1095

Berdasarkan Gambar 5 terlihat bahwa panelis memberikan penilaian agak suka terhadap tempe kacang komak dengan jenis pembungkus yang berbeda. Menurut panelis, aroma tempe kacang komak agak langu yang merupakan bau khas tempe. Menurut Santoso (2009), aroma langu dihasilkan oleh adanya aktivitas enzim lipoksigenase yang secara alami terdapat pada kacang kacang-kacangan yang dapat menguraikan lemak pada kacang komak sebesar 4,8\% menjadi senyawa-senyawa penyebab bau langu.

\section{Kesukaan Tekstur}

Berdasarkan data hasil pengamatan dan analisis keragaman menunjukkan bahwa penggunaan jenis daun memberikan pangaruh yang tidak berbeda nyata terhadap kesukaan tekstur tempe kacang komak.Penilaian panelis terhadap kesukaan tekstur tempe kacang komak dapat dilihat pada Gambar 6 .

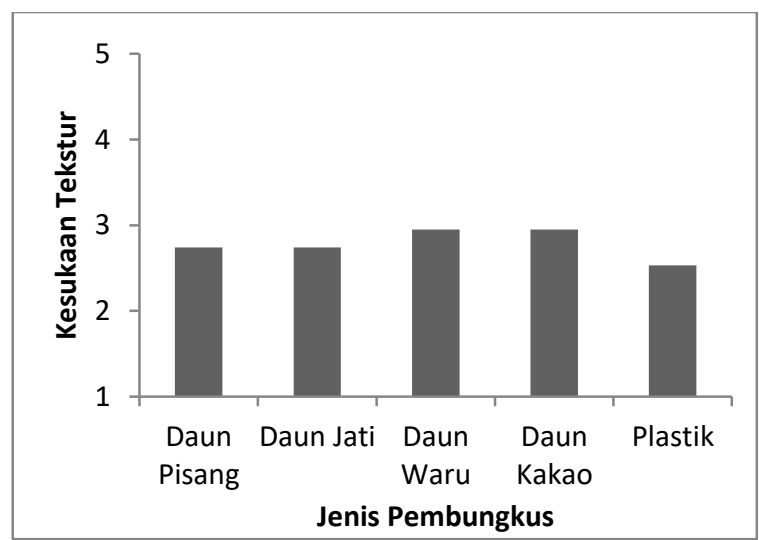

Gambar 6. Grafik Pengaruh Beberapa Jenis Pembungkus terhadap Kesukaan Tekstur Tempe Kacang Komak Selama Fermentasi.

Penilaian panelis terhadap kesukaan tekstur tempe kacang komak menyebutkan agak menyukainya. Menurut panelis tekstur tempe kacang komak yang dihasilkan bertekstur agak padat padat sehingga lebih disukai panelis dibandingkan tempe kacang komak pada perlakuan lainnya. Padatnya tekstur tempe kacang komak pada perlakuan ini diduga disebabkan oleh pertumbuhan misselium kapang yang menyerupai benang putih tumbuh menyebar dan merata pada permukaan biji komak dan membentuk suatu jaringan yang padat sehingga terjadi pengikatan yang kompak diantara biji komak. 
Hal ini sesuai dengan pernyataan Karsono dkk (2008) menyatakan bahwa tekstur tempe yang baik yaitu tekstur tempe yang terikat padat dan tidak mudah hancur apabila dipegang dan diremas.

\section{Kesukaan Rasa}

Berdasarkan data hasil pengamatan dan analisis keragaman menunjukkan bahwa penggunaan jenis daun memberikan pangaruh yang berbeda nyata terhadap kesukaan rasa tempe kacang komak. Penilaian panelis terhadap kesukaan rasa tempe kacang komak dapat dilihat pada Gambar 7.

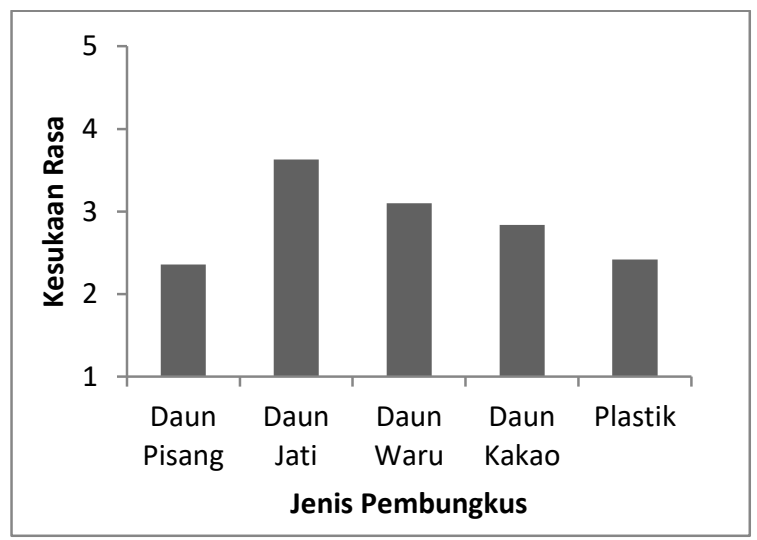

Gambar 7. Grafik Pengaruh Beberapa Jenis Pembungkus terhadap Kesukaan Rasa Tempe Kacang Komak Selama Fermentasi

Berdasarkan Gambar 7 terlihat bahwa panelis menyukai tempe kacang komak yang dibungkus menggunakan daun jati. Hal ini diduga karena terdapatnya kandungan flavonoid pada daun jati yang memberikan rasa serta aroma yang wangi. Kresno (2008) mengatakan bahwa daun jati dimanfaatkan secara tradisional di Jawa sebagai pembungkus makanan. Aroma daun-daun pembungkus tersebut biasanya terbawa pada makanan yang diwadahi. Tempe yang dibungkus dengan daun jati terasa lebih nikmat.

\section{KESIMPULAN}

Perlakuan penggunaan beberapa jenis pembungkus memberikan pengaruh yang berbeda nyata terhadap kadar protein, dan kesukaan rasa tempe kacang komak, namun memberikan pengaruh yang tidak berbeda nyata terhadap kadar air, kadar abu, kesukaan aroma dan tekstur tempe kacang komak. Tempe kacang komak dengan pembungkus daun jati menunjukkan kesukaan panelis tertinggi terhadap kesukaan rasa, dengan kadar air 63,64\%, kadar abu 0,51\% dan kadar protein $11,52 \%$.

\section{DAFTAR PUSTAKA}

Astawan, I. M., 2004. Tetap Sehat dengan Produk Makanan Olahan. Tiga Serangkai. Solo.

Ati N.H., P. Rahayu, S. Notoesoedarmo, dan L. Limantara, 2006. Komposisi dan Kandungan Pigmen Tumbuhan Pewarna Alami Kain Tenun Ikat di Kabupaten Timor Tengah Selatan. Propinsi Nusa Tenggara Timur.

Badan Standarisasi Nasional, 2009. Standar Mutu Tempe SNI 3144-2009. Badan Standarisasi Nasional. Jakarta.

Duke, J. A., 1983. Handbook of Legumes of World Economic Importance.Plenum Press. New York.

Francis, F.J., 2000. "Starch" dalam Willey Encyclopedia of Food Science and Technology.John Willey and Sons, Inc. New York.

Hidayat, N., M.C. Padaga dan S. Suhartini, 2006. Mikrobiologi Industri.Penerbit Andi.Yogyakarta.

Karsono Y,. A. Tunggal, A. Wiratama, dan P. Adimulyo, 2008. Pengaruh Jenis Kultur Starter terhadap Mutu Organoleptik Tempe Kedelai. Departemen Ilmu dan Teknologi Pangan Institut Pertanian Bogor. Bogor.

Karrupiah, P., dan M. Mustaffa. 2013. Anttibacterial and Antioxidant Activities of Musa sp. Leaf Extracts Againts Multidrug Resistant Clinical Pathogens Causing Nosocomial Infection. Asian Pasific Journal of Tropical Biomedicine 3(9): 737-742. https://doi.org/10.1016/S22211691(13)60148-3

Meenashree, B., V.J. Vasanthi, dan R.N.I. Mary. 2014. Evaluation of Total Phenlic Content and Antimicrobial Activities Exhibited by The Leaf Extracts of Musa acuminata (Banana). International Journal of Current Microbiology and Applied Sciences. 3(5): 136-141. 
Minifie, B.W., 1970. Chocolate, Cocoa and

Confentionary : Science and Tecnology . Avi Coonecticut. USA.

Osman, H., R. Nasarudin, dan S.L. Lee, 2004. Extracts of Cocoa (Theobroma cacao L.) Leaves and Their Antioxidation Potential. Food Chemistry 86(1):4146.

DOI: $10.1016 /$ j.foodchem.2003.08.02 6

Rahayu, W. P., 1998. Penuntun Praktikum Penilaian Organoleptik. Fakultas Teknologi Pertanian. Institut Pertanian Bogor. Bogor.

Santoso, 2009. Susu dan Yoghurt Kedelai. Laboratorium Kimia Pangan Fakultas Pertanian Universitas Widyagama. Malang.

Sudarmadji, S, S., B. Haryono dan Suhardi, 2007. Prosedur Analisa Untuk Bahan Makanan dan Pertanian. Penerbit Liberty. Yogyakarta. 